https://helda.helsinki.fi

\title{
The effect of buffer strip width and selective logging on riparian forest microclimate
}

\section{Olden, Anna}

2019-12-01

Olden , A , Peura , M , Saine , S , Kotiaho , J S \& Halme , P 2019 , ' The effect of buffer strip width and selective logging on riparian forest microclimate ' , Forest Ecology and Management, vol. 453 , 117623 . https://doi.org/10.1016/j.foreco.2019.117623

http://hdl.handle.net/10138/335101

https://doi.org/10.1016/j.foreco.2019.117623

cc_by_nc_nd

acceptedVersion

Downloaded from Helda, University of Helsinki institutional repository.

This is an electronic reprint of the original article.

This reprint may differ from the original in pagination and typographic detail.

Please cite the original version. 
1 Title: The effect of buffer strip width and selective logging on riparian forest

2 microclimate

4 Authors: Anna Oldén ${ }^{1,2}$, Maiju Peura ${ }^{1,2}$, Sonja Saine ${ }^{1,3}$, Janne S. Kotiaho ${ }^{1,2}$ \& Panu Halme ${ }^{1,2}$

51 Department of Biological and Environmental Science, P.O. Box 35, Fl-40014 University of Jyväskylä,

6 Finland

72 School of Resource Wisdom, P.O. Box 35, Fl-40014 University of Jyväskylä, Finland

83 Organismal and Evolutionary Biology Research Programme, University of Helsinki, P.O. Box 65,

9 Helsinki Fl-00014, Finland

10 Corresponding author: Anna Oldén, anna.m.olden@jyu.fi, Department of Biological and

11 Environmental Science, P.O. Box 35, Fl-40014 University of Jyväskylä, Finland

Declarations of interest: none

\section{Abstract}

Riparian forests have cool and humid microclimates, and one aim of leaving forested buffer strips between clear-cut areas and streams is to conserve these microclimatic conditions. We used an experimental study set up of 35 streamside sites to study the impacts of buffer strip width (15 or 30 meters) and selective logging within the buffer strips on summer-time air temperature, relative air humidity and canopy openness 12 years after logging. The buffer strip treatments were compared to unlogged control sites. We found that 15-meter buffer strips with or without selective logging and 30-meter buffer strips with selective logging were insufficient in maintaining temperature, relative humidity and canopy openness at similar levels than they were in control sites. In contrast, 30-meter buffer strips differed only little from control sites, but they did have significantly lower mean air humidity. Microclimatic changes were increased by southern or southwestern aspect of the clearcut, and by logging on the opposite side of the stream. We also tested how the cover of three indicator mosses (Hylocomium splendens, Pseudobryum cinclidioides and Polytrichum commune) had changed (from pre-logging to 12 years post-logging) in relation to post-logging air temperature, relative air humidity and canopy openness. We found that each of the species responded to at least one of these physical conditions. Air humidity was the most significant variable for explaining changes in the cover of the indicator moss species, suggesting that the changes in this microclimatic component has biological impacts. We conclude that to preserve riparian microclimatic conditions and species dependent on those, buffer strips should exceed 30 meters in width, and not be selectively logged. Wider buffer strips are required if the clear-cut is towards south or southwest, or if the two sides of the stream are logged at the same time or during subsequent years.

\section{Keywords}

Canopy openness; moss; partial harvesting; refugia; relative humidity; selective logging; streamside; temperature; continuous cover forestry 
Streamside riparian zones consist of the ecotone between the stream and upland forest. They host high biodiversity due to the complexity in soil conditions, topography and microclimate (Hylander et al., 2005; Naiman and Décamps, 1997). In addition to many species typical to upland forests, the riparian zones host species that are adapted to moist soil and flooding (MacDonald et al., 2014; Naiman and Décamps, 1997). Although the area of riparian forests is small in the boreal landscape (a few percent), they form a habitat network of high connectivity, which may enhance the dispersal of organisms (Johansson et al., 1996; Naiman and Décamps, 1997). Thus, protecting the integrity of the riparian forests surrounding watercourses should be a high priority of biodiversity conservation in managed forest landscapes (Fries' et al., 1998; Naiman et al., 1993). However, riparian forests and their biodiversity are threatened by intensive forestry, and in North America and Europe more than $80 \%$ of riparian corridors have already been disturbed or destroyed (Naiman et al., 1993).

Nowadays, buffer strips are left between streams and clear-cuts, but it is still uncertain what width is enough to conserve the microclimatic conditions and species in the riparian zones (e.g Hylander, 2014; Moore et al., 2005; Selonen and Kotiaho, 2013; Sweeney and Newbold, 2014).

Compared to intact forest, the forest edge adjacent to a clear-cut has higher daytime temperatures (but slightly lower at night), lower daytime relative air humidity, higher soil temperature, higher wind speed and more solar radiation (Chen et al., 1995; Moore et al., 2005). In upland forests, solar radiation and soil temperature acclimate to interior forest levels at about the distance of one tree length, while it takes a longer distance for air temperature, wind speed and, especially, relative air humidity (Chen et al., 1995; Moore et al., 2005). The depth of the edge effects is affected by several factors, with aspect being of large importance: in the northern hemisphere, edge effects are largest and deepest on south- or southwest-facing edges (Chen et al., 1995; Heithecker and Halpern, 2007; Moore et al., 2005). It is not well known how the edge effect is affected if the retained forest is selectively logged. When the canopy becomes less dense, it results in a longer, less steep edge effect (Heithecker and Halpern, 2007). On the other hand, it has been suggested that a feathered edge with a dense understory is more resistant to physical edge effects (Chen et al., 1995), and better mimics the edges created by e.g. wildfires (Braithwaite and Mallik, 2012).

Results on the depth of the edge effect in upland forests do not necessarily apply in riparian forests, where logging may have smaller effects on the microclimate and communities because the naturally moister and cooler microclimate may buffer against the changes (Dynesius et al., 2009; MacDonald et al., 2014; Rykken et al., 2007). The study of Brosofske et al. (1997) suggested that buffer strips should be at least 45 meters wide to protect the natural riparian microclimate, while in the study of Rykken et al. (2007) buffer strips of 30 meters were sufficient. In terms of species, the buffer width should be at least 30 meters in order to protect communities of vascular plants and mosses that grow in the riparian habitat next to the stream (Elliott and Vose, 2016; Oldén et al., 2019; Selonen and Kotiaho, 2013) as well as aquatic species (Sweeney and Newbold, 2014). Selective logging in the buffer strip increases the density of stream macroinvertebrates (Carlson et al., 1990), increases the regeneration of saplings in the buffer (Mallik et al., 2014; Zenner et al., 2012), and decreases the amount of decaying wood in the long-term (Lundström et al., 2018). It also causes changes in moss communities in 15-meter wide buffers but not in 30-meter wide buffers (Oldén et al., 2019). However, studies on the effects of selective logging on riparian microclimate are lacking.

Bryophytes (mosses and liverworts) are excellent bioindicators for studying the possible responses of species to changed microclimatic conditions in riparian buffer strips (Hylander et al., 2005, 2002; Stewart and Mallik, 2006). They are poikilohydric, i.e. they cannot regulate their water loss and are dependent on moisture from the soil and air to retain growth (Proctor, 1990). Many species, especially those adapted to grow under forest canopy, are very sensitive to logging-induced changes in moisture and light conditions (Busby et al., 1978; Dynesius and Hylander, 2007; Hylander et al., 2005, 2002; Stewart and Mallik, 2006). Studies have shown that bryophyte growth, cover, species richness and community composition change soon after clearcutting or logging with narrow buffers, 
indicating low resistance to change (Hylander et al., 2005, 2002; MacDonald et al., 2014; Oldén et al., 2019; Stewart and Mallik, 2006). Small populations may survive in microclimatic refugia on the northern side of objects, such as boulders or stumps (Schmalholz and Hylander, 2011).

In Finland, those riparian streamside habitats that are in natural or nearly natural condition are protected by law, the Forest Act. The Act states that it is not allowed to alter their characteristic features, which are specified as the special growing conditions and microclimate that result from the proximity of water and the tree and shrub layers (Forest Act, 2013). However, the width of buffer strips has been on average 15 meters in streamsides classified as Forest Act Habitats (Ahonen, 2017), while the latest recommendation is that the buffer width should equal the average length of the trees (Metsäkeskus, 2018), i.e. around 20 meters, which is probably also insufficient to conserve the microclimate and growing conditions. Thus, there is a contrast between the $>30$ meters suggested by earlier studies, the reality in the field, and the law.

In this paper, we study the impact of buffer strip width (15 or 30 meters) and selective logging (30\% of tree basal area removed from the buffer or not) on summer-time microclimatic conditions and canopy openness in streamsides. We compare the conditions in the logged sites to unlogged control sites 12 years after the logging treatments in order to answer the following questions: 1 . What kind of buffer strips in our set up, if any, are able to maintain relative air humidity, air temperature and canopy openness at similar levels than in unlogged sites? 2. How are air humidity and temperature affected by buffer width, selective logging and the aspect of the clear-cut? 3 . Are the differences in humidity and temperature smaller on the northern side of a tree than on the southern side, i.e. can objects like trees create small microclimatic refugia? In addition, we compare the effects of air humidity, air temperature and canopy openness on the changes that have happened in the cover of three common indicator moss species between pre-logging and 12 years post-logging in order to answer the question: 4 . Which physical conditions drive the changes in the cover of the three mosses?

\section{Material and methods}

\subsection{Study sites}

The study area is located in Central and Eastern Finland, on southern and middle boreal vegetation zones (Ahti et al., 1968). The mean annual air temperature in the area is $2-4{ }^{\circ} \mathrm{C}$ and precipitation $600-700 \mathrm{~mm}$ year $^{-1}$ (average from 1981-2010) (Pirinen et al., 2012). We studied 35 streamside sites in the area (Table 1). Each site was located on a separate stream. Before the logging treatments, all study sites were dominated by even-aged spruce (Picea abies (L.) H. Karst.), and the dominant trees were at least 80 years old. The sites were completely forested, i.e. spruce trees grew close to the stream and there were no extensive treeless riparian zones. The water channels were small streams or rivulets with regular, year-round flow. The width of the water channels varied from 0.2 to 3.2 meters (Table 1). The sites did not have extensive regular flooding, but occasional flooding could occur especially near the stream. All of the sites had been classified as Forest Act Habitats by Finnish forest authorities.

Table 1. The study sites: Municipality of the location, North and East coordinates in decimal degrees, width of the stream and the total basal area of trees before logging treatments. The sites are listed based on their treatments.

\begin{tabular}{|c|c|c|c|c|c|}
\hline Site ID & Municipality & $\mathrm{N}$ & $E$ & $\begin{array}{l}\text { Stream } \\
\text { width (m) }\end{array}$ & $\begin{array}{l}\text { Tree basal } \\
\text { area }\left(\mathrm{m}^{2} / \mathrm{ha}\right)\end{array}$ \\
\hline
\end{tabular}




\begin{tabular}{|c|c|c|c|c|c|}
\hline & & & & & \\
\hline & Vieremā & 63.94052 & 26.66638 & 1.0 & 36 \\
\hline 21 & Lieksa & 63.23884 & 30.75467 & 1.6 & 32 \\
\hline 27 & Leivonmäki & 61.90145 & 25.92199 & 1.5 & 27 \\
\hline 28 & Leivonmäki & 62.02793 & 26.18217 & 0.6 & 24 \\
\hline 31 & Kuhmoinen & 61.71589 & 24.93035 & 0.4 & 13 \\
\hline 35 & Sotkamo & 63.93125 & 28.22158 & 3.2 & 32 \\
\hline 45 & Rautavaara & 63.59531 & 28.48888 & 2.1 & 26 \\
\hline 47 & Rautavaara & 63.63822 & 28.44861 & 0.8 & 32 \\
\hline $30 \mathrm{~m}$ with & out selective & ogging & & & \\
\hline 4 & Vieremä & 63.98945 & 26.8938 & 0.3 & 35 \\
\hline 16 & Lieksa & 63.46902 & 29.8989 & 0.5 & 25 \\
\hline 25 & Kivijärvi & 63.20412 & 24.90234 & 1.9 & 27 \\
\hline 34 & Uurainen & 62.54641 & 25.48799 & 2.5 & 25 \\
\hline 40 & Rautavaara & 63.66626 & 28.57471 & 0.2 & 27 \\
\hline $30 \mathrm{~m}$ with & selective loge & & & & \\
\hline 15 & Kaavi & 63.11614 & 28.73192 & 0.6 & 37 \\
\hline 18 & Lieksa & 63.46808 & 29.94605 & 0.3 & 37 \\
\hline 23 & Äänekoski & 62.56329 & 25.51531 & 1.2 & 23 \\
\hline 26 & Korpilahti & 62.04014 & 25.42641 & 1.1 & 31 \\
\hline 33 & Karstula & 62.97202 & 24.97654 & 1.7 & 22 \\
\hline 39 & Rautavaara & 63.67432 & 28.56051 & 0.4 & 30 \\
\hline 42 & Nurmes & 63.56566 & 29.33364 & 0.6 & 29 \\
\hline 43 & Nurmes & 63.57713 & 29.50002 & 0.3 & 26 \\
\hline $15 \mathrm{~m}$ with & out selective & ogging & & & \\
\hline 1 & Vieremä & 63.83188 & 26.94863 & 0.3 & 37 \\
\hline 2 & Pieksämäki & 62.39258 & 26.93276 & 1.5 & 33 \\
\hline 29 & Korpilahti & 62.21604 & 25.39608 & 0.8 & 31 \\
\hline 32 & Orivesi & 61.6162 & 24.20887 & 0.6 & 23 \\
\hline 38 & Rautavaara & 63.40632 & 28.20288 & 0.7 & 32 \\
\hline $15 \mathrm{~m}$ with & selective loge & & & & \\
\hline 3 & Vieremä & 63.98682 & 26.90886 & 0.5 & 40 \\
\hline 8 & Pielavesi & 63.39579 & 26.39757 & 0.2 & 37 \\
\hline 17 & Lieksa & 63.46600 & 29.89691 & 1.6 & 33 \\
\hline 20 & Lieksa & 63.28729 & 30.34200 & 1.1 & 36 \\
\hline 22 & Lieksa & 63.21131 & 30.22918 & 0.4 & 37 \\
\hline 24 & Pihtipudas & 63.41049 & 26.05685 & 0.8 & 34 \\
\hline 48 & Rautavaara & 63.59369 & 28.45654 & 0.7 & 36 \\
\hline 49 & Nurmes & 63.78579 & 29.35355 & 0.7 & 38 \\
\hline 56 & Pieksämäki & 62.26919 & 26.99563 & 2.2 & 46 \\
\hline
\end{tabular}

\subsection{Treatments}

During the winter 2005-2006, logging treatments were applied on 27 of the sites, while 8 sites were left as unlogged controls. The logging treatments included clear-cutting in the upland forest, and one of the following types of buffer strips next to the stream:

1. 30-meter wide buffer strip without selective logging (5 sites),

2. 30-meter wide buffer strip with selective logging (8 sites), 
3. 15-meter wide buffer strip without selective logging (5 sites),

4. 15-meter wide buffer strip with selective logging (9 sites).

In the selective logging, $30 \%$ of the basal area of trees was logged from the buffer strip, focusing on the largest trees of the stand. Trees were logged within the whole width of the buffer. Additional information on the treatments can be found in Oldén et al. (2019). The treatments were allocated randomly to the sites.

Originally, the logging treatment was performed on only one side of the stream, and mature forest was left standing on the opposite side. If by the year 2017 logging had also happened on the opposite side of the stream, we measured the distance from the stream to the edge of the clear cut, and sites where the distance was less than 40 meters were recorded as logged on the opposite side. In these 15 sites the opposite buffers had not been selectively logged, but the buffer width varied both within sites and between sites from about 10 to 40 meters (mean of site means was 23 meters). In the 20 unlogged sites there were no buffer strip loggings within 50 meter distance from the study area, but in some of them there were clear-cuts further than 50 meters away. Since these clear-cuts were mostly tens or hundreds of meters away, it was considered that they did not impact the microclimate of the study area considerably.

\subsection{Data collection: Microclimate and canopy openness}

On each study site there was a rectangular $10 \mathrm{~m} * 15 \mathrm{~m}$ study area next to the stream. One of the 10-meter sides of the study area followed the stream shoreline. The study area was placed in the center of the treatment area, i.e. the logged area was on the same side of the stream.

We used data loggers (Lascar EL-USB-2) to measure relative humidity and air temperature at 5minute time intervals for a month between $18^{\text {th }}$ of July and $18^{\text {th }}$ of August 2017. Each data logger contains one sensor for relative humidity (accuracy $2.25 \%$ ) and temperature (accuracy $0.55^{\circ} \mathrm{C}$ ). Two data loggers were placed on a trunk of a mature spruce tree located at a distance of about 7.5 meters from the stream, and as near to the center of the 10-meter wide study area as possible (Figure 1). The loggers were placed at $50 \mathrm{~cm}$ height from the ground, on the opposite sides, south and north, of the tree. From the data of each logger, we calculated the following values: the mean relative air humidity (\%), the mean of daily minimum relative air humidities (\%), the standard deviation (SD) of all of the relative air humidity values, the mean air temperature $\left({ }^{\circ} \mathrm{C}\right)$, the mean of daily maximum air temperatures $\left({ }^{\circ} \mathrm{C}\right)$, and the standard deviation of all of the temperature values.

To measure canopy openness in 2017, we took fisheye-photos and calculated the proportion of visible sky from the pixels. Four photos were taken (one towards each cardinal direction) at both of the lowest corners of the study area at the shoreline (Figure 1). The average proportion of visible sky in these eight photos was used to approximate the openness at 0-meter distance from the stream. Similarly, four photos were taken at a distance of 10 meters from the stream, along both of the edges of the study area, and these eight photos were used to approximate the openness at 10meter distance. The photos were taken with a digital camera and a fish-eye converter that allows for photos with 120 degrees angle of view. For each photo, the camera was held vertically so that the upper edge was upright. The proportion of sky pixels out of all pixels in the photo was calculated with ImageJ 1.45s (a more detailed description of the method given in Oldén et al., 2017). 


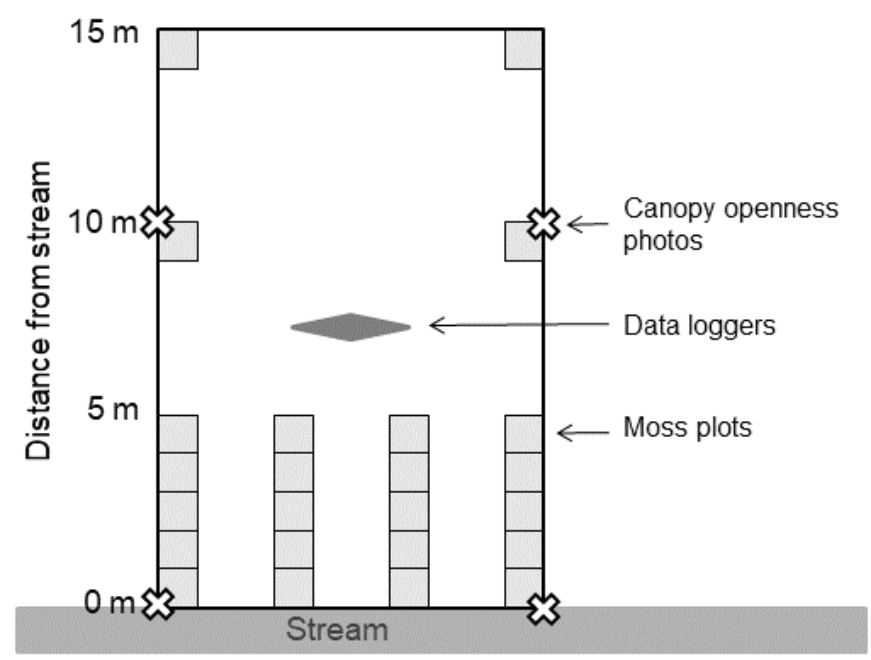

Figure 1. The location of canopy openness photos, data loggers and moss plots within the study area next to the stream.

\subsection{Data collection: Mosses}

\subsubsection{Indicator mosses}

In order to test for the ecological significance of the physical conditions (humidity, temperature and canopy openness), we followed the change in the cover of three common indicator moss species. Hylocomium splendens (Hedw.) Schimp., Pseudobryum cinclidioides (Huebener) T.J.Kop., and Polytrichum commune Hedw. differ in their ecology from each other, but are known to require moist microhabitats and to respond to microclimatic changes:

1. H. splendens is a feather moss that forms loose wefts (intertwining branched layers) on boreal forest floors. H. splendens dries out quickly in dry conditions, so it thrives in relatively constant, shaded habitat conditions, where trees provide high humidity and low temperatures (Callaghan et al., 1978). The growth of $H$. splendens has been shown to decrease due to logging-induced microclimatic edge effects (Caners et al., 2013; Hylander, 2005; Stewart and Mallik, 2006).

2. P. cinclidioides is a large-leaved moss that grows as turf (vertical stems with little or no branching). It grows on mesotrophic, waterlogged soil in springs, swamps, flooded mires, flood meadows and stream banks (Darell and Cronberg, 2011; Ulvinen et al., 2002). P. cinclidioides has been observed to decrease in retention patches after the surrounding forest is logged (Perhans et al., 2009).

3. P. commune is a tall turf moss that grows commonly on peat in mires and in paludified spots in forests (Ulvinen et al., 2002). It has an underground stem, internal water-conducting tissues and complex leaves that are resistant to water loss (Bayfield, 1973). Due to these properties $P$. commune is able to grow also in periodically dry and exposed conditions (Callaghan et al., 1978).

\subsubsection{Cover change}

The percentage cover of each of the three study species was estimated (by eye estimation) in 2004 (before logging) and in 2017 (12 years after logging) on $1 \mathrm{~m}^{2}$ plots within the study area. Twenty plots were located within the first five meters from the stream (distance 0-5 meters) and four additional plots were located at 10 and 15 meters from the stream (Figure 1). The sampling was focused on the first five meters from the stream because the primary aim of leaving buffer strips is 
In 2017, several plots were discarded on many of the sites due to the following reasons: 1) the plot markings had been lost and the plot could not be placed with certainty in the same place than in 2004,2 ) the microhabitats in the plot had changed substantially due to windfalls (there was a root mound, a log or a pile of branches on the plot), or 3) the stream had meandered and the shoreline had moved. These plots were not included in the data of either year.

For each species, we calculated the mean cover on the studied plots in 2004 and in 2017, and then calculated the relative change in the cover as $\left(\mathrm{Cover}_{2017}-\mathrm{Cover}_{2004}\right) /\left(\mathrm{Cover}_{2004}+\mathrm{Cover}_{2017}\right)$. When the change in the cover is divided by the sum, the relative change gets a maximum value of 1 (colonization) and a minimum value of -1 (extinction).

\subsection{Statistical analyses}

We used Multivariate Analysis of Variance (MANOVA) to analyse the data where several response variables were affected at the same time and were correlated with each other. MANOVA is used to test whether the explanatory variables affect the response variables simultaneously in their global model. All analyses were performed in $\mathrm{R}$ ( $\mathrm{R}$ Core Team, 2017). Function Im was used to build the separate linear models for each response variable, and function Anova from package "car" (Fox and Weisberg, 2011) was used to perform the Analysis of Variance with type III sums of squares (suitable for unbalanced designs).

\section{The response variables in the models were}

1) Relative humidity: mean humidity, mean daily minimum humidity and the standard deviation of humidity (mean values from the two data loggers on a site),

2) Temperature: mean temperature, mean daily maximum temperature and the standard deviation of temperature (mean values from the two data loggers on a site),

3) Canopy openness: canopy openness at 0 meters from stream and canopy openness at 10 meters from stream (means of the eight canopy openness photos taken at that distance in a site).

First, we tested how each of the four different kinds of buffer strips (the treatments) differed from the unlogged controls, i.e. whether one or more of the buffer strip types could provide similar microclimatic conditions as unlogged sites. We used three MANOVAs, one for the humidity variables, one for the temperature variables and one for the canopy openness variables. Prior to analysis, both of the canopy openness values were log10-transformed to improve the model fit. In each model, the explanatory variables were the treatment (controls compared to the four buffer treatments: $30 \mathrm{~m}$ without selective logging, $30 \mathrm{~m}$ with selective logging, $15 \mathrm{~m}$ without selective logging, and $15 \mathrm{~m}$ with selective logging), logging on the opposite side of the stream (yes or no), and east coordinates of the geographic location. North coordinates could not be added in the model because they correlated with logging on the opposite side (more sites had been logged in south than north of the geographic area) and with east coordinates (the sites were located within the geographic area so that those that were more in north also tended to be more in east).

Second, we used four MANOVAs to test how relative humidity and temperature were affected by buffer width, selective logging and southern or southwestern aspect in the buffer strip treatment sites. Control sites were not included in these analyses as aspect is not relevant without a clear-cut, and there was no buffer width or selective logging in the controls. The compass point of the treatment clear-cut from the stream was transformed into an index of southern aspect, which has a value of 180 if the clear-cut is towards south, decreases continuously through 90 in east and west, and is 0 if the clear-cut is towards north. Similarly, southwestern aspect is 180 if the clear-cut is towards southwest, and 0 if the clear-cut is towards northeast. Separate models were built for southern and southwestern aspects. Each model included the following explanatory variables: Buffer 
width (15 or 30), selective logging (yes or no), southern or southwestern aspect (0-180), logging on the opposite side of the stream (yes or no) and east coordinates. We also included the interactions buffer width * selective logging and buffer width * southern/southwestern aspect, but these did not have significant impacts in any of the models, and we excluded them from the final models.

Third, to test whether microclimatic changes are smaller on the northern side of a tree than on the southern side of the tree, we built two similar MANOVAs separately for the south- and north-facing data loggers. Separate models were built for relative humidity and temperature. Only the logging treatment was included as an explanatory variable in these MANOVAs, and we compared the strength of the treatment effects on the models of south-facing loggers and north-facing loggers.

Fourth, we used three MANOVAs to test for the effect of humidity, temperature and canopy openness on the changes in the cover of the three moss species. In all of the three models, the response variables were the same: the relative change in $H$. splendens, relative change in $P$. cinclidioides and relative change in $P$. commune. In the humidity model, the explanatory variable was mean humidity, and in the temperature model, it was mean temperature (means of the two loggers on the site). In the canopy openness model, the explanatory variable was the mean of the canopy openness values at 0 and 10 meters.

For those readers who are interested in the impacts of the treatments, buffer width, selective logging and logging on the opposite side of the stream on the relative changes of the three indicator mosses, we provide these analyses in Appendix A.

\section{Results}

\subsection{Impact of logging on physical conditions}

The treatments had a strong impact on the humidity variables, and logging on the opposite side and the east coordinate also had an impact in the global MANOVA model (Table 2). When compared to the control sites, all of the four types of buffer strips had lower mean humidity (Figure $2 \mathrm{~A}$ ), and mean humidity was also lowered by logging on the opposite side of the stream (Table 3 ). In terms of the mean daily minimum humidity, the 30-meter buffers without selective logging did not differ significantly from control sites, while all other treatments had significantly lower values (Figure 2 B), and the minimum humidity values were also lowered by logging on the opposite side of the stream (Table 3). All buffer strips, except for the 30-meter buffers without selective logging, had higher variation (standard deviation) in humidity (Figure $2 \mathrm{C}$ ). The standard deviation was also increased by logging on the opposite side and by an eastern location in the geographic area (Table 3).

The treatments and logging on the opposite side had significant impacts on the temperature values in their global model, but east coordinate did not (Table 2). Mean temperature was increased on the logged treatments, but only the 15-meter buffer strips (with or without selective logging) differed significantly from controls (Figure $2 \mathrm{D}$ ). Mean temperature was also increased by logging on the opposite side of the stream (Table 3). In terms of the mean daily maximum temperature and the standard deviation of temperature, all treatments except the 30-meter buffers without selective logging had significantly higher values than the controls (Figure $2 \mathrm{E}$ and F). In addition, logging on the opposite side also increased the daily maximum and the standard deviation of temperature (Table 3).

Canopy openness was affected by both the treatments and by the logging on the opposite side, but not by the east coordinate (Table 2). At the stream shoreline, only the 15-meter buffer strips with selective logging had significantly higher canopy openness than control sites (Figure $2 \mathrm{G}$ ). Logging on the opposite side increased canopy openness at stream shoreline (Table 3). At the distance of 10 
meters, all buffer strips, except for the 30-meter buffers without selective logging, had significantly higher canopy openness than control sites (Figure $2 \mathrm{H}$ ). Logging on the opposite side increased canopy openness as well (Table 3 ).

Table 2. Results from the three MANOVAs on the impact of treatments (unlogged control vs. buffer strip treatments), logging on the opposite side and east coordinate on relative air humidity (mean, daily minimum and standard deviation), temperature (mean, daily maximum and standard deviation) and canopy openness (at 0 and 10 meters from stream). The three separate MANOVAs are separated by horizontal lines. Pillai test statistic, approximate Fstatistic, hypothesis and error degrees of freedom, and p-value.

\begin{tabular}{|c|c|c|c|c|c|c|c|}
\hline Response & Explanatory & Pillai & $\mathbf{F}$ & Hypoth. df & Error df & p & Sign. \\
\hline \multirow[t]{3}{*}{ Humidity } & Treatment logging & 0.94 & 3.2 & 12 & 84 & 0.001 & $* * *$ \\
\hline & Opposite logging & 0.26 & 3.1 & 3 & 26 & 0.043 & $*$ \\
\hline & East coordinate & 0.29 & 3.5 & 3 & 26 & 0.029 & $*$ \\
\hline \multirow[t]{3}{*}{ Temperature } & Treatment logging & 0.82 & 2.6 & 12 & 84 & 0.005 & $* *$ \\
\hline & Opposite logging & 0.30 & 3.8 & 3 & 26 & 0.022 & $*$ \\
\hline & East coordinate & 0.19 & 2.1 & 3 & 26 & 0.129 & \\
\hline \multirow[t]{3}{*}{ Canopy openness } & Treatment logging & 0.59 & 3.0 & 8 & 56 & 0.008 & $* *$ \\
\hline & Opposite logging & 0.37 & 8.1 & 2 & 27 & 0.002 & $* *$ \\
\hline & East coordinate & 0.11 & 1.6 & 2 & 27 & 0.213 & \\
\hline
\end{tabular}
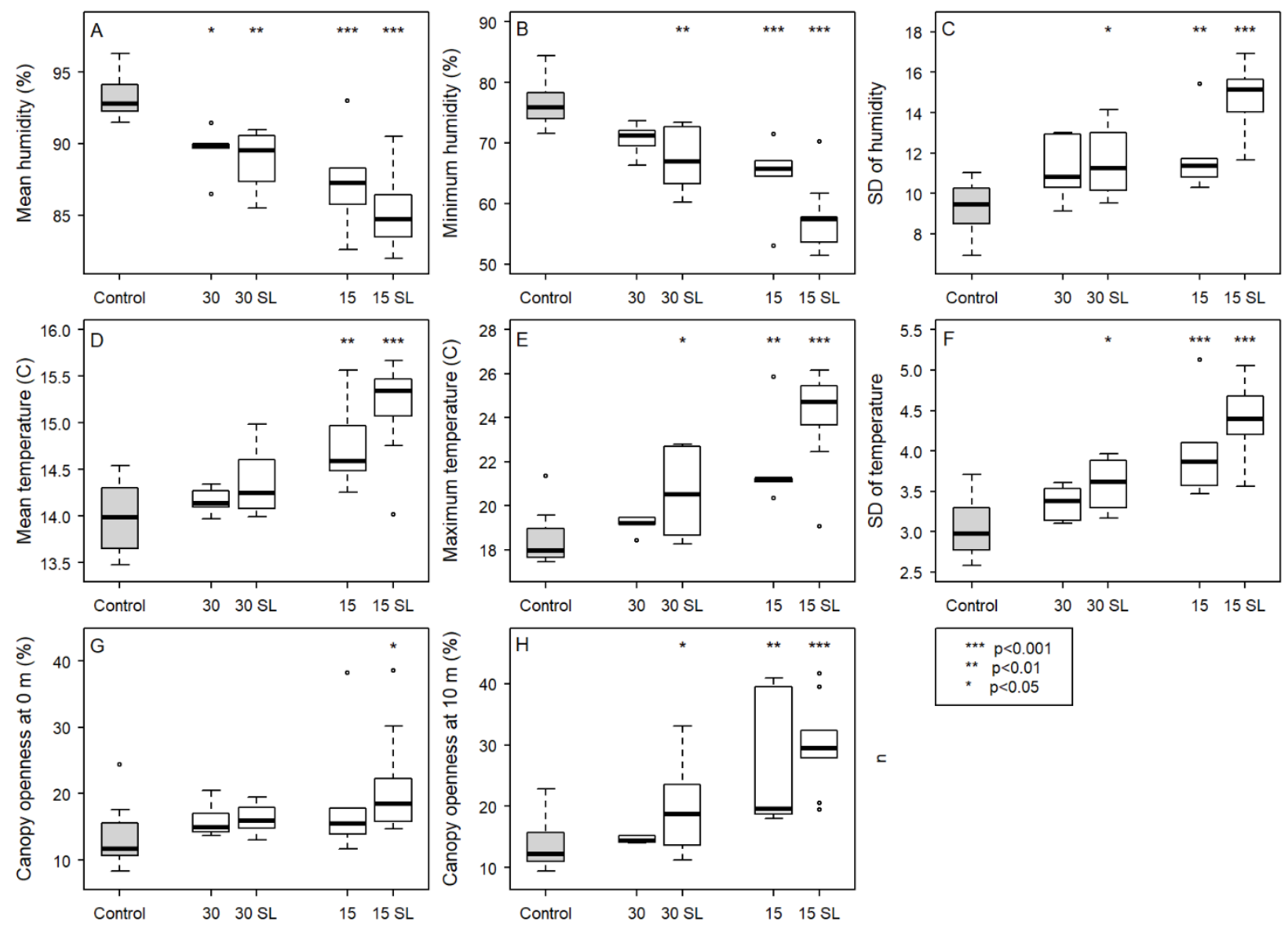

Figure 2. The differences between unlogged control sites and the sites with buffer strips (30-meter without or with selective logging [SL] and 15-meter without or with selective logging) in their 
323

physical conditions: A) mean relative humidity, B) mean daily minimum humidity, C) standard deviation of humidity, D) mean temperature, E) mean daily maximum temperature, F) standard deviation of temperature, G) canopy openness at stream shoreline, an $\mathrm{H}$ ) canopy openness at 10-meter distance from stream.

Table 3. Results from the eight linear models on the effects of logging on the opposite side of the stream and east coordinate on the humidity, temperature and canopy openness variables. Opposite logging and east coordinates were modelled together with the effects of treatment loggings (results in Figure 2).

\begin{tabular}{llllllll}
\hline Response & \multicolumn{3}{l}{ Explanatory } & & & & \\
& Logging on opposite side & \multicolumn{2}{l}{ East coordinate } & \\
& Estimate & $\mathbf{p}$ & Sign. & Estimate & p & Sign. \\
\hline Mean humidity & -2.47 & 0.012 & $*$ & $-9.6 \mathrm{E}-06$ & 0.066 &. \\
Minimum humidity & -5.80 & 0.005 & $* *$ & $-2.1 \mathrm{E}-05$ & 0.054 &. \\
SD of humidity & 1.87 & 0.004 & $* *$ & $1.0 \mathrm{E}-05$ & 0.005 & $* *$ \\
Mean temperature & 0.36 & 0.037 & $*$ & $7.0 \mathrm{E}-07$ & 0.440 & \\
Maximum temperature & 1.85 & 0.014 & $*$ & $4.4 \mathrm{E}-06$ & 0.264 & \\
SD of temperature & 0.54 & 0.002 & $* *$ & $1.9 \mathrm{E}-06$ & 0.033 & $*$ \\
Canopy openness at 0 $\mathrm{m}$ & 0.17 & $<0.001$ & $* * *$ & $4.6 \mathrm{E}-07$ & 0.079 &. \\
Canopy openness at 10 $\mathrm{m}$ & 0.12 & 0.024 & $*$ & $1.9 \mathrm{E}-07$ & 0.490 & \\
\hline \multicolumn{7}{c}{ Significance: ${ }^{* * *} \mathrm{p}<0.001,{ }^{* *} 0.001<\mathrm{p}<0.1,{ }^{*} 0.1<\mathrm{p}<0.05, .0 .05<\mathrm{p}<0.1$}
\end{tabular}

\subsection{Impact of buffer width, selective logging and aspect on microclimate}

Buffer width (15 or 30 meters) had significant impacts on the humidity and temperature variables (Table 4). Selective logging (yes or no) did not have significant impacts, although it did have a nearly significant impact on humidity when modelled together with southern aspect (Table 4). Both southern and southwestern aspects impacted the humidity variables significantly, but the temperature variables were not affected by southwestern aspect and southern aspect had a nearly significant impact (Table 4).

Table 4. Results from four MANOVAs on the effects of buffer width, selective logging and aspect (southern or southwestern) on the humidity (mean, SD and mean daily minimum) and temperature (mean, SD and mean daily maximum) on sites with buffer strips. Logging on the opposite side of the stream and east coordinates were also included as additional explanatory vairiables. The four separate MANOVAs are separated by horizontal lines. Pillai test statistic, approximate F-statistic, hypothesis and error degrees of freedom, and $\mathrm{p}$-value.

\begin{tabular}{|c|c|c|c|c|c|c|c|}
\hline Response & Explanatory & Pillai & $\mathbf{F}$ & Hypoth. df & Error df & $\mathbf{p}$ & Sign. \\
\hline \multirow[t]{10}{*}{ Humidity } & Buffer width & 0.49 & 6.0 & 3 & 19 & 0.005 & $* *$ \\
\hline & Selective logging & 0.30 & 2.8 & 3 & 19 & 0.071 & . \\
\hline & Southern aspect & 0.46 & 5.4 & 3 & 19 & 0.008 & $* *$ \\
\hline & Logging on opposite side & 0.38 & 3.9 & 3 & 19 & 0.026 & $*$ \\
\hline & East coordinate & 0.45 & 5.1 & 3 & 19 & 0.009 & $* *$ \\
\hline & Buffer width & 0.46 & 5.3 & 3 & 19 & 0.008 & $* *$ \\
\hline & Selective logging & 0.25 & 2.1 & 3 & 19 & 0.136 & \\
\hline & Southwestern aspect & 0.33 & 3.2 & 3 & 19 & 0.049 & $*$ \\
\hline & Logging on opposite side & 0.23 & 1.9 & 3 & 19 & 0.161 & \\
\hline & East coordinate & 0.28 & 2.4 & 3 & 19 & 0.099 & \\
\hline
\end{tabular}




\begin{tabular}{lllllll}
\hline Temperature & Buffer width & 0.58 & 8.7 & 3 & 19 & $0.001^{* * *}$ \\
Selective logging & 0.27 & 2.3 & 3 & 19 & 0.111 & \\
Southern aspect & 0.28 & 2.4 & 3 & 19 & 0.097. &. \\
Logging on opposite side & 0.38 & 3.8 & 3 & 19 & $0.027^{*}$ \\
East coordinate & 0.28 & 2.4 & 3 & 19 & 0.098. \\
\hline Buffer width & 0.54 & 7.5 & 3 & 19 & $0.002^{* *}$ \\
Selective logging & 0.23 & 1.9 & 3 & 19 & 0.167 & \\
Southwestern aspect & 0.09 & 0.7 & 3 & 19 & 0.589 & \\
Logging on opposite side & 0.32 & 3.0 & 3 & 19 & 0.059. \\
East coordinate & 0.23 & 1.9 & 3 & 19 & 0.161 \\
\hline
\end{tabular}

Significance: ${ }^{* * *} p<0.001,{ }^{* *} 0.001<p<0.1,{ }^{*} 0.1<p<0.05, .0 .05<p<0.1$

337

\subsection{Microclimatic refugia on northern side of trees}

Air humidity was affected by the treatments on both the southern and northern sides of the trees (Table 5). Air temperature was affected more strongly on the southern than on the northern side, but the effect was significant on the northern side as well (Table 5).

Table 5. Results from the four MANOVAs on the impact of treatments on air humidity (mean, daily minimum and standard deviation) and temperature (mean, daily maximum and standard deviation) on the southern and northern sides of trees. The four separate MANOVAs are separated by horizontal lines. Pillai test statistic, approximate F-statistic, hypothesis and error degrees of freedom, and $\mathrm{p}$-value.

\begin{tabular}{|c|c|c|c|c|c|c|c|}
\hline Response & Explanatory & Pillai & $\mathbf{F}$ & Hypoth. df & Error df & p & Sign. \\
\hline $\begin{array}{l}\text { Humidity in south-facing } \\
\text { loggers }\end{array}$ & Treatment logging & 0.89 & 3.2 & 12 & 90 & $<0.001$ & $* * *$ \\
\hline $\begin{array}{l}\text { Humidity in north-facing } \\
\text { loggers }\end{array}$ & Treatment logging & 0.97 & 3.6 & 12 & 90 & $<0.001$ & $* * *$ \\
\hline $\begin{array}{l}\text { Temperature in south-facing } \\
\text { loggers }\end{array}$ & Treatment logging & 0.81 & 2.8 & 12 & 90 & 0.003 & $* *$ \\
\hline $\begin{array}{l}\text { Temperature in north-facing } \\
\text { loggers }\end{array}$ & Treatment logging & 0.69 & 2.2 & 12 & 90 & 0.016 & $*$ \\
\hline
\end{tabular}

\subsection{Impact of physical conditions on mosses}

Mean humidity, mean temperature and mean canopy openness each explained significantly the changes in the cover of the three moss species, and mean humidity had the strongest effect among the three variables (Table 6).

Table 6. Results from the three MANOVAs on the impacts of mean humidity, mean temperature and mean canopy openness on the change in the cover of three moss species $(H$. splendens, $P$. cinclicioides and P. commune). The three separate MANOVAs are separated by horizontal lines. Pillai test statistic, approximate F-statistic, hypothesis and error degrees of freedom, and p-value.

\begin{tabular}{llllllll}
\hline Response & Explanatory & Pillai & $\mathbf{F}$ & Hypoth. $\mathbf{d f}$ & Error $\mathbf{~ d f}$ & $\mathbf{p}$ & Sign. \\
\hline \multirow{2}{*}{ Mosses } & Mean humidity & 0.39 & 6.7 & 3 & 31 & 0.001 & ${ }^{* *}$ \\
\cline { 2 - 8 } & Mean temperature & 0.24 & 3.3 & 3 & 31 & 0.033 & $*$ \\
\cline { 2 - 8 }
\end{tabular}


The relative change in the cover of $H$. splendens was affected by humidity, which had a significant positive impact, while temperature and canopy openness did not have significant impacts on this species (Figure $3 \mathrm{~A}-\mathrm{C}$ ). Similarly, the relative change of $P$. cinclidioides was significantly and positively affected by humidity, while temperature and canopy openness did not have significant effects (Figure $3 \mathrm{D}-\mathrm{F}$ ). In contrast, the relative change in $\mathrm{P}$. commune was significantly affected by all three variables: negatively by humidity, and positively by temperature and canopy openness (Figure $3 \mathrm{G}-1$ ). Canopy openness had the largest impact on P. commune (Figure $3 \mathrm{I}$ ).

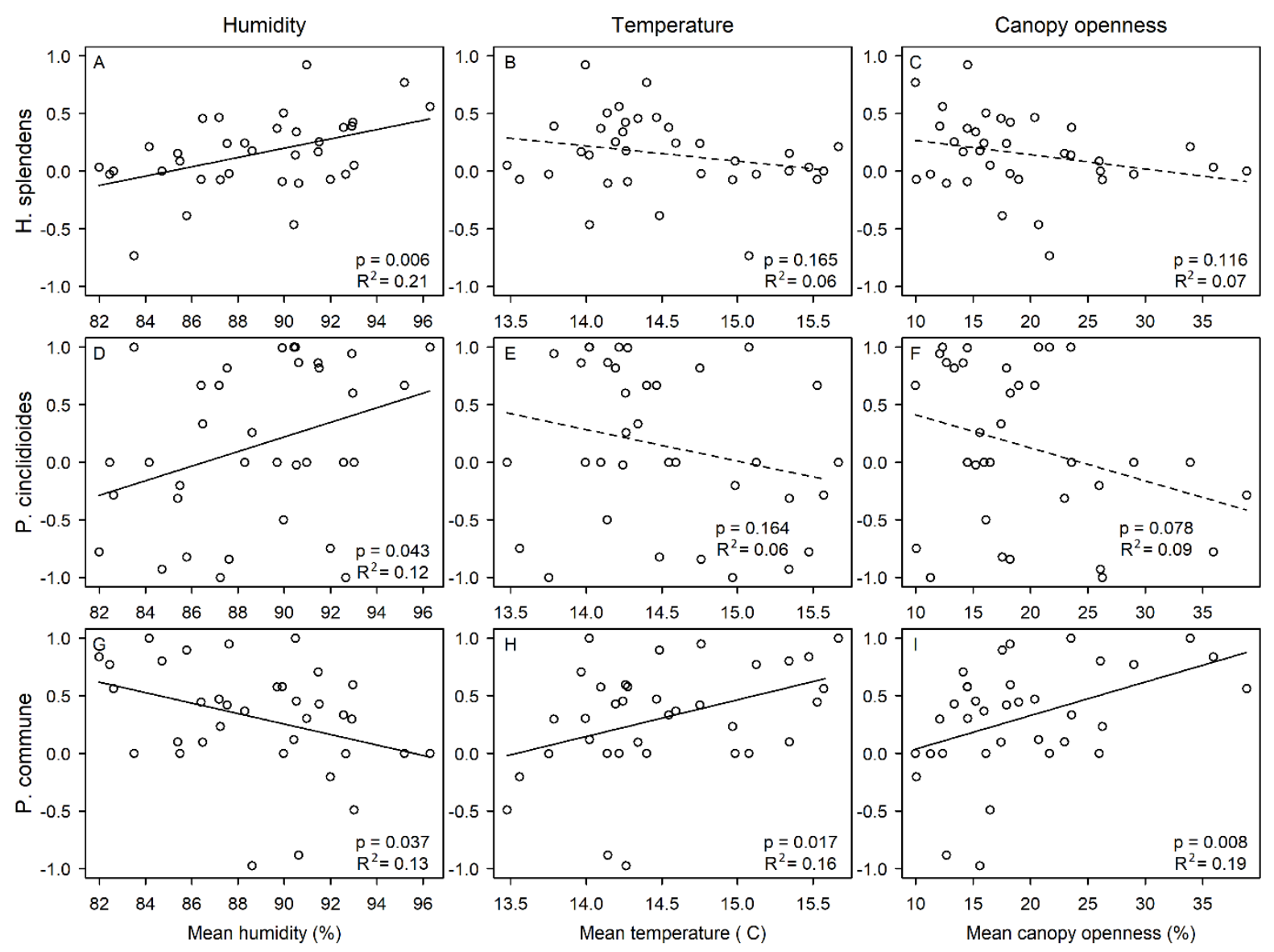

Figure 3. The impacts of mean relative humidity, mean temperature and mean canopy openness on the relative changes that have occurred in the cover of the three moss species (from prelogging to 12 years post-logging): A-C) Hylocomium splendens, D-F) Pseudobryum cinclidioides, and G-I) Polytrichum commune. Solid regression lines indicate significant relationships $(p<0.05)$ and dashed lines indicate non-significant relationships $(p<0.05)$.

\section{Discussion}

\subsection{Impact of logging on physical conditions}

We found strong impacts of logging on the measured microclimatic variables of air temperature and relative humidity. As expected, the divergence from control site microclimates was in the order 15meter selectively logged $>15$-meter without selective logging $>30$-meter selectively logged $>30$ - 
meter without selective logging. The effects were similar for canopy openness at 10 meters from the stream, while right at the stream shoreline only the most intensive logging (15 m selective logging) resulted in significant difference from controls.

The 15-meter wide buffers, both those with and without selective logging, differed from control sites in their microclimate. They had lower humidity and higher temperature, and both humidity and temperature varied more. These logging-induced changes in microclimate are well known near clearcut edges in upland forests (Chen et al., 1995; Moore et al., 2005). Obviously, 15-meter buffers do not fulfil the criteria of no changes in microclimate and are therefore illegal in Finnish Forest Act habitats (Forest Act, 2013), although they have been common in practice (Ahonen, 2017). Our measurements were made 12 years after logging, when the newly regenerated trees already provided some protection, but there had also been abundant windfalls in many sites with 15-meter buffers, which had resulted in more microclimatic changes by the time of our measurements.

Maximum daily temperature and minimum daily humidity differed more from the values found in control sites than did the means of temperature and humidity. For example, in the sites with 15meter selectively logged buffers, mean temperature was on average $1.2^{\circ} \mathrm{C}$ higher while mean daily maximum temperature was $5.6^{\circ} \mathrm{C}$ higher than in controls, and mean humidity was $8.1 \%$ lower while mean daily minimum humidity was $19.0 \%$ lower. This is because at night unlogged forests are somewhat warmer than logged areas, and the stream humidifies the surrounding air (Moore et al., 2005; Rykken et al., 2007). The changes in the heat and dryness of the hottest time of the day may be detrimental to sensitive organisms.

The differences in mean and maximum temperatures are comparable to the expected effects of climate change in the area (mean temperature increases by $2-3^{\circ} \mathrm{C}$ and the mean temperature of the annual hottest day increases by $1.5-2{ }^{\circ} \mathrm{C}$ if global warming is limited to $1.5^{\circ} \mathrm{C}$; Hoegh-Guldberg et al., 2018). However, climate change happens over several decades, while logging changes the microclimate immediately (or in a time span of a few years if there are subsequent windfalls), leaving very little time for sensitive organisms to adapt or migrate. It is likely that within a few decades, the joined effect of climate change and logging causes peak temperatures of the logged streamsides to increase by several degrees compared to present values. In addition, logging with narrow buffers destroys the possibilities of cool and humid streamsides to function as microclimatic refugia or dispersal corridors during climate change (see Ashcroft, 2010; Fremier et al., 2015; Isaak et al., 2015). All this adds pressure to secure wide buffer strips.

Microclimatic changes were smaller in 30-meter buffers. On average, both the selectively logged and the non-selectively logged 30-meter buffers were warmer and dryer and had more variation than did the unlogged controls, but the difference from controls was mostly significant for only the selectively logged ones. However, in the case of mean relative humidity also the 30-meter buffers without selective logging were drier than control sites. Thus, based on our data, 30-meter wide buffers are nearly wide enough to retain microclimatic conditions in streamside forests, but the buffers should not be selectively logged. Our results are supported by Brosofske et al. (1997) who found that 45meter buffers are mostly sufficient to protect riparian microclimatic gradients, and by the study of Rykken et al. (2007) where 30-meter buffers were sufficient to retain similar microclimate as unlogged forests. Thus, buffer width should exceed 30 meters when the aim is to conserve microclimatic conditions in valuable habitats. Probably the buffer width should be about 40-50 meters, but more studies are needed to confirm this suggestion. On the other hand, if the primary aim of leaving a buffer strip is not to conserve the microclimate, narrower or selectively logged buffer strips can be sufficient. Selective logging within buffers may provide better emulation of natural disturbances and increase habitat diversity and tree regeneration (Kreutzweiser et al., 2012; Mallik et al., 2014). Therefore, selective logging could be applied in sites where microclimatic protection is not considered necessary, thus increasing habitat heterogeneity at the landscape-scale. 
425 Logging on the opposite side of the stream had significant impacts on all of the measured

426 temperature, humidity and canopy openness variables. This implies that a wider buffer should be left if the other side has been logged recently, or there is a risk that it will be logged before the currently logged area has reached high enough growing stock for resisting edge effects (in Finnish conditions we expect this to happen in about three decades). Finally, additional variables such as topography, hydrology or the sensitivity of the species communities, should be considered wherever possible to modify buffer width case-by-case. For example, streamsides with groundwater discharge or frequent flooding may be especially sensitive and may require wider buffers (Kuglerová et al., 2014). If the retained buffer is too narrow to retain the microclimate and specific biodiversity values in the particular streamside, it is not cost-efficient at all, because it concurs economic costs but the most sensitive species are lost anyway.

\subsection{Impact of buffer width, selective logging and aspect on microclimate}

Buffer width exerted a much stronger impact on relative air humidity and temperature than did selective logging within the buffer. This is not surprising as the two buffer strip treatments (15 or 30 meters) differed by $50 \%$ tree removal, while selective logging removed $30 \%$ of tree basal area. The buffer width causes so much microclimatic changes that additional changes caused by selective logging are smaller. However, the selectively logged sites differed more from controls than those that were not selectively logged (see Figure 2). Thus, although buffer width seems to be the most important factor determining microclimatic conditions, selective logging does exert some additional changes. This is most likely due to canopy gaps resulting in increased solar radiation and increased air temperature (Gray et al., 2002). In upland forests, forest density is the main driver of summer temperature minima and maxima (Greiser et al., 2018), and selective logging results in clear microclimatic changes (Zheng et al., 2000). In addition, microclimatic edge effects reach deeper into the forest when the forest is more open (Heithecker and Halpern, 2007; Schmidt et al., 2017). On the other hand, selective logging within the riparian buffer results in increased regeneration of tree saplings and shrubs (Mallik et al., 2014; Zenner et al., 2012), which may provide microclimatic protection (Kovács et al., 2017). As our sites had been logged 12 years before the measurements, the shrubs and saplings can be already quite large, which may explain why the impact of selective logging seems to be relatively small. In our study, the trees were removed evenly from the whole width of the buffer strip, but the microclimate might be better protected by uneven logging where more trees are removed closer to the clear-cut edge.

Southern or southwestern aspect of the clear-cut increased the impacts of the logging actions on relative air humidity, and southern aspect also caused a small impact on air temperature. These results are mostly in accordance with earlier results on the effects of aspect in upland forest edges (Chen et al., 1995; Heithecker and Halpern, 2007; Moore et al., 2005). However, buffer width and logging on the opposite side did cause larger impacts than aspect, especially on temperature. Therefore, we recommend leaving buffer strips of more than 30 meters on all aspects, but protecting air humidity requires even wider buffers if the clear-cut will be towards south or southwest.

\subsection{Microclimatic refugia on northern side of trees}

We did not find evidence that the northern side of spruce trunks could provide small-scale microclimatic refugia. Both humidity and temperature variables were affected by the logging treatments on both the northern and southern sides of the trees. For the humidity variables, the northern side of the trees did not provide any protection compared to the southern sides. Thus, for species that are sensitive to changes in air humidity, there are no refugia on northern sides of trees in riparian forests. For the temperature variables, the treatments caused larger differences on the southern sides of trees than on northern sides of trees. This is most likely due to more sunlight on the southern side, which heats up the tree bark as well as the data logger, and respectively the 
organisms on it. Therefore, for those species that suffer from logging-induced increases in radiation or temperature, there is a higher chance of survival on the northern sides of trees. However, on the northern sides of the trees there were still differences in temperature between control sites and treatment sites, which weakens the refugia.

Schmalholz and Hylander (2011) found that the northern sides of boulders and stumps provided refugia for forest floor bryophytes on clear-cuts, where the microclimate changes more drastically than in riparian buffers. It may be that the base of large boulders or large stumps provide more constant microclimatic conditions also in riparian buffers. In addition, organisms that grow on the forest floor, especially in concave depressions, are better protected than those on convex substrates such as tree bases (Hylander et al., 2005).

\subsection{Impact of physical conditions on mosses}

The relative change in the cover of the three model moss species was affected by each of the physical factors: mean relative humidity, mean temperature and canopy openness. Thus, the logging-induced changes in the microclimatic conditions do result in changes in sensitive species communities, which is in accordance with earlier studies from riparian buffer strips of various widths (Elliott and Vose, 2016; Hylander et al., 2005; Oldén et al., 2019). The most significant of the three variables was air humidity, which had a significant impact on the relative change of each of the three moss species. This shows that changes in humidity must be avoided to prevent changes in moss communities.

The relative change in the cover of the forest floor moss Hylocomium splendens was affected by humidity: the cover of the species had increased in sites with high humidity and decreased or stayed at the same level in sites with low humidity. Earlier studies have shown that the growth of $H$. splendens decreases due to microclimatic edge effects, in both riparian buffers (Stewart and Mallik, 2006) and in retained upland forest patches (Caners et al., 2013; Hylander, 2005). Water is the major limiting factor for the growth of $\mathrm{H}$. splendens, because it does not have an internal water conducting system and under dry conditions it dries out quickly (Callaghan et al., 1978). Busby et al. (1978) showed that the growth of $\mathrm{H}$. splendens was affected positively by precipitation frequency and negatively by evaporation stress. Light and temperature were not significant factors in controlling growth rates (Busby et al., 1978), which is in accordance with our results of no significant impacts of temperature or canopy openness on the change in the species cover. Callaghan et al. (1978) showed that the photosynthesis of $H$. splendens is positively affected by higher temperatures, but in high temperature respiration exceeds gross photosynthesis, and therefore the growth of the species is favored by low temperature.

Similarly to H. splendens, the relative change in the cover of Pseudobryum cinclidioides was also positively affected by mean air humidity. This exemplifies that even the riparian species that grow on the inundated soil right next to the stream may suffer from changed air humidity due to logging 1530 meters away from the stream. The decline in the abundance of $P$. cinclidioides in retention patches has been recorded also by Perhans et al. (2009). The large leaves of the species may be efficient in photosynthesizing in moist and humid conditions, but they are likely to dry out if air humidity decreases, and even high soil moisture may not be able to buffer against this. Therefore, $P$. cinclidioides could be used as an indicator species when studying microclimatic changes in riparian communities. However, in our study sites the species often had low cover, and therefore even small changes in cover results in large changes in relative cover, causing much variation in the data. $P$. cinclidioides typically grows beside the stream in the zone that is inundated for a short period during spring and then is waterlogged during the rest of the growing season (Darell and Cronberg, 2011). For this reason, a better study setup for this species would have more study plots right next to the stream. 
Polytrichum commune showed an opposite response to increasing changes in microclimate: the relative cover increased in sites with low humidity, high temperature and high canopy openness. $P$. commune has an underground stem system, internal water conducting tissues and complex leaves that are able to resist water loss, which enables the species to photosynthesize in dry conditions (Bayfield, 1973). Instead of water availability, the growth of $P$. commune is limited by light availability, and for this reason it grows fast in habitats where there is little shadow from other vegetation (Callaghan et al., 1978). In addition, P. commune spreads efficiently to bare soil patches via both sexual reproduction and vegetative reproduction from underground stems (Callaghan et al., 1978). Thus, the death of other mosses due to damage from logging machinery or microclimatic stress creates suitable habitats for this opportunistic moss.

We do not have pre-logging microclimatic data from the sites and therefore it is not possible to analyze the effects of the treatments on changes that have happened in microclimate from prelogging to post-logging. The fact that the moss changes from pre-logging to post-logging correlate well with the post-logging microclimatic data implies that there have indeed been logging-induced changes in the buffer strip sites. Also, the results show that the microclimatic conditions, which were measured in only one point at the height of 0.5 meters, caused changes in mosses that respond to the conditions in their immediate surroundings at the ground-level. This indicates that moist soil conditions or field layer vegetation were not enough to protect the ground-dwelling mosses against the larger microclimatic changes within the site. On the other hand, only 15-meter buffers trips resulted in significant changes in the relative covers of the mosses, while the impacts were more varied for sites with 30-meter buffers trips (see Appendix A). More comprehensive studies with more sites, more plots and more species are needed to confirm the minimum buffer width that is adequate to conserve mosses.

\section{Conclusions}

We compared the microclimatic conditions in four different buffer strip treatments and unlogged controls, and found that all the treatments affected some or all of the microclimate variables. The conditions in 15-meter buffer strips (with or without selective logging) or in 30-meter buffer strips with selective logging were so different from controls that they clearly do not meet the requirements for no change in microclimate set by the Finnish Forest Act (Forest Act, 2013).

The 30-meter buffer strips without selective logging differed only little from controls, but they did have significantly lower mean air humidity. The differences in mean air humidity between all of the sites correlated with the responses of the three indicator moss species, suggesting that the changes in this microclimatic component has biological impacts. In addition, we found no evidence of the possibility of the northern side of large trees (or other similar objects) to provide microclimatic refugia for species that are sensitive to changes in air humidity, although species sensitive to high radiation and temperature might survive better on the northern side of the trees.

We conclude that to preserve riparian microclimatic conditions and species dependent on those, buffer strips between the stream and the clear-cut should exceed 30 meters. We do not recommend evenly distributed selective logging (of about $30 \%$ basal area) even within wide buffer strips. Extra wide buffer strips should be considered if the aspect of the clear-cut is towards south or southwest, or if the two sides of a stream are logged at the same time or during subsequent years. It is preferable to avoid logging both sides during subsequent decades.

\section{Acknowledgements}


We are grateful to Hennariikka Mäenpää for help with data collection and to Ville A.O. Selonen for the original plan of the set up. We want to thank Tornator Oyj, Metsämannut Oy, Metsä Group and Metsähallitus for giving permissions to conduct the study on their land, and Metsäteho Oy for performing the logging actions. The study was funded by the Finnish Ministry of Agriculture and Forestry.

\section{References}

Ahonen, A., 2017. Metsälain 10 §:n mukaisten puron- ja noronvarsien rajaus uudistushakkuissa Hämeenkyrön ja Kangasalan kunnissa (In Finnish with English summary). Bachelor's thesis. Häme University of Applied Sciences.

Ahti, T., Hämet-Ahti, L., Jalas, J., 1968. Vegetation zones and their sections in northwestern Europe. Ann. Bot. Fenn. 5, 169-211.

Ashcroft, M.B., 2010. Identifying refugia from climate change. J. Biogeogr. 37, 1407-1413. https://doi.org/10.1111/j.1365-2699.2010.02300.x

Bayfield, N.G., 1973. Notes on water relations of Polytrichum commune Hedw. J. Bryol. 7, 607-617.

Braithwaite, N.T., Mallik, A.U., 2012. Edge effects of wildfire and riparian buffers along boreal forest streams. J. Appl. Ecol. 49, 192-201. https://doi.org/10.1111/j.1365-2664.2011.02076.x

Brosofske, K.D., Chen, J., Naiman, R.J., Franklin, J.F., 1997. Harvesting effects on microclimatic gradients from small streams to uplands in western Washington. Ecol. Appl. 7, 1188-1200. https://doi.org/10.1890/1051-0761(1997)007[1188:HEOMGF]2.0.CO;2

Busby, J.R., Bliss, L.C., Hamilton, C.D., 1978. Microclimate control of growth rates and habitats of the boreal forest mosses, Tomenthypnum nitens and Hylocomium splendens. Ecol. Monogr. 48, 95-110.

Callaghan, T. V., Collins, N.J., Callaghan, C.H., 1978. Photosynthesis, growth and reproduction of Hylocomium splendens and Polytrichum commune in Swedish Lapland. Oikos 31, 73-88.

Caners, R.T., Ellen Macdonald, S., Belland, R.J., 2013. Linking the biological traits of boreal bryophytes to forest habitat change after partial harvesting. For. Ecol. Manage. 303, 184-194. https://doi.org/10.1016/j.foreco.2013.04.019

Carlson, J.Y., Andrus, C.W., Froehlich, H.A., 1990. Woody debris, channel features, and macroinvertebrates of streams with logged and undisturbed riparian timber in Northeastern Oregon, U.S.A. Can. J. Fish. Aquat. Sci. 47, 1103-1111.

Chen, J., Franklin, J.F., Spies, T.A., 1995. Growing-season microclimatic gradients from clearcut edges into old-growth Douglas-fir forests. Ecol. Appl. 5, 74-86.

Darell, P., Cronberg, N., 2011. Bryophytes in black alder swamps in south Sweden: habitat classification, environmental factors and life-strategies. Lindbergia 34, 9-29.

Dynesius, M., Hylander, K., 2007. Resilience of bryophyte communities to clear-cutting of boreal stream-side forests. Biol. Conserv. 135, 423-434. https://doi.org/10.1016/j.biocon.2006.10.010

Dynesius, M., Hylander, K., Nilsson, C., 2009. High resilience of bryophyte assemblages in streamside compared to upland forests. Ecology 90, 1042-1054. https://doi.org/10.1890/07-1822.1 
Elliott, K.J., Vose, J.M., 2016. Effects of riparian zone buffer widths on vegetation diversity in southern Appalachian headwater catchments. For. Ecol. Manage. 376, 9-23. https://doi.org/10.1016/j.foreco.2016.05.046

Forest Act, 2013. Metsälaki $10 \S(20.12 .2013 / 1085)$ - Forest Act $10 \S(20.12 .2013 / 1085)$. Finlex. https://www.finlex.fi/en/laki/kaannokset/1996/en19961093.

Fox, J., Weisberg, S., 2011. An $\{$ R $\}$ Companion to Applied Regression, Second Edition. Thousand Oaks CA: Sage. URL: http://socserv.socsci.mcmaster.ca/jfox/Books/Companion.

Fremier, A.K., Kiparsky, M., Gmur, S., Aycrigg, J., Craig, R.K., Svancara, L.K., Goble, D.D., Cosens, B., Davis, F.W., Scott, J.M., 2015. A riparian conservation network for ecological resilience. Biol. Conserv. 191, 29-37. https://doi.org/10.1016/j.biocon.2015.06.029

Fries', C., Lindén, G., Nillius, E., 1998. The stream model for ecological landscape planning in nonindustrial private forestry. Scand. J. For. Res. 13, 370-378. https://doi.org/10.1080/02827589809382996

Gray, A.N., Spies, T.A., Easter, M.J., 2002. Microclimatic and soil moisture responses to gap formation in coastal Douglas-fir forests. Can. J. For. Res. 32, 332-343. https://doi.org/10.1139/x01-200

Greiser, C., Meineri, E., Luoto, M., Ehrlén, J., Hylander, K., 2018. Monthly microclimate models in a managed boreal forest landscape. Agric. For. Meteorol. 250-251, 147-158. https://doi.org/10.1016/j.agrformet.2017.12.252

Heithecker, T.D., Halpern, C.B., 2007. Edge-related gradients in microclimate following structural retention harvests in western Washington. For. Ecol. Manage. 248, 163-173.

Hoegh-Guldberg, O., Jacob, D., Taylor, M., Bindi, M., Brown, S., Camilloni, I., Diedhiou, A., Djalante, R., Ebi, K.L., Engelbrecht, F., Guiot, J., Hijioka, Y., Mehrotra, S., Payne, A., Seneviratne, S.I., Thomas, A., Warren, R., Zhou, G., 2018. Impacts of $1.5^{\circ} \mathrm{C}$ of Global Warming on Natural and Human Systems, in: Masson-Delmotte, V., P. Zhai, H.-O. Pörtner, D. Roberts, J. Skea, P.R. Shukla, A. Pirani, W. Moufouma-Okia, C. Péan, R. Pidcock, S. Connors, J.B.R. Matthews, Y. Chen, X. Zhou, M.I. Gomis, E. Lonnoy, T. Maycock, M. Tignor, T.W. (Ed.), Global Warming of $1.5^{\circ} \mathrm{C}$. An IPCC Special Report on the Impacts of Global Warming of $1.5^{\circ} \mathrm{C}$ above Pre-Industrial Levels and Related Global Greenhouse Gas Emission Pathways, in the Context of Strengthening the Global Response to the Threat of Climate Change,. IPCC, pp. 175-311.

Hylander, K., 2014. Living on the edge: effectiveness of buffer strips in protecting biodiversity in boreal riparian forests. PhD thesis. Umeå University.

Hylander, K., 2005. Aspect modifies the magnitude of edge effects on bryophyte growth in boreal forests. J. Appl. Ecol. 42, 518-525. https://doi.org/10.1111/j.1365-2664.2005.01033.x

Hylander, K., Dynesius, M., Jonsson, B.G., Nilsson, C., 2005. Substrate form determines the fate of bryophytes in riparian buffer strips. Ecol. Appl. 15, 674-688.

Hylander, K., Jonsson, B.G., Nilsson, C., 2002. Evaluating buffer strips along boreal streams using bryophytes as indicators. Ecol. Appl. 12, 797-806.

Isaak, D.J., Young, M.K., Nagel, D.E., Horan, D.L., Groce, M.C., 2015. The cold-water climate shield: delineating refugia for preserving salmonid fishes through the 21st century. Glob. Chang. Biol. 21, 2540-2553. https://doi.org/10.1111/gcb.12879 
Johansson, M.E., Nilsson, C., Nilsson, E., 1996. Do rivers function as corridors for plant dispersal? J. Veg. Sci. 7, 593-598. https://doi.org/10.2307/3236309

Kovács, B., Tinya, F., Ódor, P., 2017. Stand structural drivers of microclimate in mature temperate mixed forests. Agric. For. Meteorol. 234-235, 11-21. https://doi.org/10.1016/j.agrformet.2016.11.268

Kreutzweiser, D.P., Sibley, P.K., Richardson, J.S., Gordon, A.M., 2012. Introduction and a theoretical basis for using disturbance by forest management activities to sustain aquatic ecosystems. Freshw. Sci. 31, 224-231. https://doi.org/10.1899/11-114.1

Kuglerová, L., Ågren, A., Jansson, R., Laudon, H., 2014. Towards optimizing riparian buffer zones: Ecological and biogeochemical implications for forest management. For. Ecol. Manage. 334, 74-84. https://doi.org/10.1016/j.foreco.2014.08.033

Lundström, J., Öhman, K., Laudon, H., 2018. Comparing buffer zone alternatives in forest planning using a decision support system. Scand. J. For. Res. 33, 493-501. https://doi.org/10.1080/02827581.2018.1441900

MacDonald, R.L., Chen, H.Y.H., Palik, B.P., Prepas, E.E., 2014. Influence of harvesting on understory vegetation along a boreal riparian-upland gradient. For. Ecol. Manage. 312, 138-147. https://doi.org/10.1016/j.foreco.2013.10.011

Mallik, A.U., Kreutzweiser, D.P., Spalvieri, C.M., 2014. Forest regeneration in gaps seven years after partial harvesting in riparian buffers of boreal mixedwood streams. For. Ecol. Manage. 312, 117-128. https://doi.org/10.1016/j.foreco.2013.10.015

Metsäkeskus, 2018. Tulkintasuosituksia metsälain 10\$:n tarkoittamien erityisen tärkeiden elinympäristöjen rajaamisesta ja käsittelystä (In Finnish).

Moore, R.D., Spittlehouse, D.L., Story, A., 2005. Riparian microclimate and stream temperature response to forest harvesting: A review. J. Am. Water Resour. Assoc. 41, 813-834. https://doi.org/10.1111/j.1752-1688.2005.tb04465.x

Naiman, R.J., Décamps, H., 1997. The ecology of interfaces: Riparian zones. Annu. Rev. Ecol. Syst. 28, 621-658.

Naiman, R.J., Decamps, H., Pollock, M., 1993. The role of riparian corridors in maintaining regional biodiversity. Ecol. Appl. 3, 209-212. https://doi.org/10.2307/1941822

Oldén, A., Komonen, A., Tervonen, K., Halme, P., 2017. Grazing and abandonment determine different tree dynamics in wood-pastures. Ambio 46, 227-236. https://doi.org/10.1007/s13280-016-0821-6

Oldén, A., Selonen, V.A.O., Lehkonen, E., Kotiaho, J.S., 2019. The effect of buffer strip width and selective logging on streamside plant communities. BMC Ecol. 19:9, 1-9. https://doi.org/10.1186/s12898-019-0225-0

Perhans, K., Appelgren, L., Jonsson, F., Nordin, U., Söderström, B., Gustafsson, L., 2009. Retention patches as potential refugia for bryophytes and lichens in managed forest landscapes. Biol. Conserv. 142, 1125-1133. https://doi.org/10.1016/j.biocon.2008.12.033

Pirinen, P., Simola, H., Aalto, J., Kaukoranta, J.P., Karlsson, P., Ruuhela, R., 2012. Tilastoja Suomen ilmastosta 1981-2010 (Climatological statistics of Finland 1981-2010). 
Proctor, M.C.F., 1990. The physiological basis of bryophyte production. Bot. J. Linn. Soc. 104, 61-77.

R Core Team, 2017. R: A language and environment for statistical computing. R Foundation for Statistical Computing, Vienna, Austria. URL https://www.R-project.org/.

Rykken, J.J., Chan, S.S., Moldenke, A.R., 2007. Headwater riparian microclimate patterns under alternative forest management treatments. For. Sci. 53, 270-280. https://doi.org/10.1093/forestscience/53.2.270

Schmalholz, M., Hylander, K., 2011. Microtopography creates small-scale refugia for boreal forest floor bryophytes during clear-cut logging. Ecography (Cop.). 34, 637-648. https://doi.org/10.1111/j.1600-0587.2010.06652.x

Schmidt, M., Jochheim, H., Kersebaum, K.C., Lischeid, G., Nendel, C., 2017. Gradients of microclimate, carbon and nitrogen in transition zones of fragmented landscapes - a review. Agric. For. Meteorol. 232, 659-671. https://doi.org/10.1016/j.agrformet.2016.10.022

Selonen, V.A.O., Kotiaho, J.S., 2013. Buffer strips can pre-empt extinction debt in boreal streamside habitats. BMC Ecol. 13, 24.

Stewart, K.J., Mallik, A.U., 2006. Bryophyte responses to microclimatic edge effects across riparian buffers. Ecol. Appl. 16, 1474-1486. https://doi.org/10.1890/10510761(2006)016[1474:BRTMEE]2.0.CO;2

Sweeney, B.W., Newbold, J.D., 2014. Streamside forest buffer width needed to protect stream water quality, habitat, and organisms: A literature review. J. Am. Water Resour. Assoc. 50, 560-584. https://doi.org/10.1111/jawr.12203

Ulvinen, T., Syrjänen, K., Anttila, S., 2002. Suomen sammalet - levinneisyys, ekologia, uhanalaisuus (In Finnish). Suomen ympäristö 560. Suomen ympäristökeskus, Helsinki.

Zenner, E.K., Olszewski, S.L., Palik, B.J., Kastendick, D.N., Peck, J.E., Blinn, C.R., 2012. Riparian vegetation response to gradients in residual basal area with harvesting treatment and distance to stream. For. Ecol. Manage. 283, 66-76. https://doi.org/10.1016/j.foreco.2012.07.010

Zheng, D., Chen, J., Song, B., Xu, M., Sneed, P., Jensen, R., 2000. Effects of silvicultural treatments on summer forest microclimate in southeastern Missouri Ozarks. Clim. Res. 15, 45-59.

(1) 